Research Report No. 21/2007

\title{
Varieties of Capitalism and the Learning Firm: Contemporary Developments in EU and German Company Law - A Comment on the Strine- Bainbridge Debate About Shared Values of Corporate Management and Labor
}

Peer Zumbansen

Osgoode Hall Law School of York University, PZumbansen@osgoode.yorku.ca

Follow this and additional works at: http://digitalcommons.osgoode.yorku.ca/clpe

\section{Recommended Citation}

Zumbansen, Peer, "Varieties of Capitalism and the Learning Firm: Contemporary Developments in EU and German Company Law A Comment on the Strine-Bainbridge Debate About Shared Values of Corporate Management and Labor" (2007). Comparative Research in Law \& Political Economy. Research Paper No. 21/2007.

http://digitalcommons.osgoode.yorku.ca/clpe/238 


\section{Comparative Research in Law \& Political Economy}

\section{CLPE RESEARCH PAPER 21/ 2007 - SPECIAL ISSUE: EU GOVERNANCE}

\section{Peer Zumbansen}

Varieties of Capitalism and the Learning Firm: Contemporary Developments in EU and German Company Law - A comment on the Strine-Bainbridge debate about shared values of corporate management and labor

EDITORS: Peer Zumbansen (Director, CLPE, Osgoode Hall Law School, Toronto), J ohn W. Cioffi (University of California at Riverside), Lindsay Krauss (Osgoode Hall Law School, Toronto, Production Editor) 

CLPE Research Paper 21/2007

Vol. 03 No. 04 (2007)

\title{
Special Symposium Issue: \\ EU Governance
}

PROCEEDINGS FROM THE $10^{\text {TH }}$ IRISH EU LAW FORUM, UNIVERSITY COLLEGE

DUBLIN, 19 JANUARY 2007

Peer Zumbansen

\section{VARIETIES OF CAPITALISM AND THE LEARNING FIRM: CONTEMPORARY DEVELOPMENTS IN EU AND GERMAN COMPANY LAW}

\begin{abstract}
Research in corporate governance and labour law has been characterised by a disjuncture in the way that scholars in each field are addressing organisational questions related to the business enterprise. While labour has eventually begun to shift perspectives from aspirations to direct employee involvement in firm management, as has been the case in Germany, to a combination of 'exit' and 'voice' strategies involving pension fund management and securities litigation, it remains to be seen whether this new stream will unfold as a viable challenge to an otherwise exclusionary shareholder value paradigm. At the same time, recent suggestions made by Vice Chancellor Strine of the Delaware Chancery Court to dare think about potentially shared commitments between management and labour underline the viability of attempts at moving the corporate governance debate beyond the confines of corporate law proper.
\end{abstract}

This paper takes the questionable divide between management and labour within the framework of a limiting corporate governance concept as a starting point to explore the institutional dynamics of the corporation, thereby building on the theory of the innovative enterprise as developed by management theorists Mary O’Sullivan and William Lazonick. Largely due to the sustained distance between corporate and labour law scholars, neither group has effectively addressed their common blind spot: a better understanding of the business enterprise itself. In the midst of an unceasing flow of affirmations of the finance paradigm of the corporation, on the one hand, and 'voice' strategies by labour, on the other, it seems to 
fall to management theorists to draw lessons from the continuing coexistence of different forms of market organisation, in which companies appear to thrive. Exploring the conundrum of 'risky' business decisions within the firm, management theorists have been arguing for the need to adopt a more sophisticated organisational perspective on companies operating on locally, regionally and transnationally shaped, and often highly volatile, market segments. Research by comparative political economists has revealed a high degree of connectivity between corporate governance and economic performance without, however, arriving at such favourable results only for shareholder value regimes. Such findings support the view that corporate governance regimes are embedded in differently shaped regulatory frameworks, characterised by distinct institutions, both formal and informal, and enforcement processes. As a result of these findings, arguments to disassociate issues of corporate governance from those of the firm's (social) responsibility (CSR) have been losing ground. Instead, CSR can be taken to be an essential part of understanding a particular business enterprise. It is the merging of a comparative political economy perspective on the corporation with one on the organisational features, structures and processes of the corporation that can help us better understand the distribution of power and knowledge within the 'learning firm'.

Keywords: corporate governance, organizational theory, innovative enterprise, learning firm, employee involvement, corporate social responsibility, European/German corporate governance

JEL classification: G34, J29, J53, K22, K33

Forthcoming in European Business Organization Law Review [EBOR] 2007.

Author Contact: Peer Zumbansen Associate Dean (Research) and Director, CLPE

Osgoode Hall Law School, York University

4700 Keele St., Toronto ON, Canada M3J 1P3

Email: pzumbansen@osgoode.yorku.ca 



\title{
Varieties of Capitalism and the Learning Firm: Contemporary Developments in EU and German Company Law
}

\author{
Peer Zumbansen*
}

\section{Introduction}

The role of the employee in the corporation is manifold. Starting with their performance of various functions, determined by the superiors, employees often play a much more differentiated role in the functioning of an organisation. It is obvious then that the form of the organisation - a small or middle-sized firm or a large, publicly traded corporation with operations around the world - has a direct impact on the role of the employee. This first observation is important if we want to avoid pursuing the question 'what role for employees in the corporation' in a one-sizefits-all manner. The size, structure, and embeddedness ${ }^{1}$ of the corporation,

\footnotetext{
* Canada Research Chair in the Transnational and Comparative Law of Corporate Governance. Osgoode Hall Law School, York University, Toronto. Email: PZumbansen@osgoode.yorku.ca. Thanks to Imelda Maher and Colin Scott for the invitation to present an earlier version of this project at the $10^{\text {th }}$ Irish EU Law Forum at the University College Dublin on 19 January 2007 and to Larry Beeferman of Harvard's Labor and Worklife Program (www.law.harvard.edu/programs/lwp) for the invitation to the 2007 "Capital Matters V - Managing Labor's Capital” Conference at Harvard Law School on 4 May 2007. Thanks to William Lazonick, Cynthia Williams, David Soskice, Fenner Stewart, Simon Archer and Gil Lan for their valuable feedback. Research for this paper was conducted under the framework of the CLPE Comparative Research in Law \& Political Economy Network at Osgoode Hall Law School, Toronto. Financial Support from the Social Sciences and Humanities Research Council of Canada (Grant \# 4102005-2421) is gratefully acknowledged.
}

1 For the origin of this concept, see Karl Polanyi, The Great Transformation: The Political and Economic Origins of Our Time (New York, 1944). It was subsequently further elaborated with a focus on networks by Mark Granovetter, 'Economic Action and Social Structure: The Problem of Embeddedness', 91 American Journal of Sociology (1985) p. 481; and Mark 
as recently highlighted again by Sanford Jacoby, ${ }^{2}$ are directly related to our assessment of the role and involvement of employees in the organisation. In turn, the shape of the organisation is driven by developments in the political economy, of which the corporate, labour law and industrial relations regimes each form a part. This regulatory framework is increasingly less a domestic affair. The increased liquidity of funds available for the financing of corporate operations worldwide has been undercutting, informing and pushing domestic policy developments. It is thus no surprise that our view on what are the 'leading political economies' shifts with the particular regime's aptness and capacity to adapt to the changing structures of world markets. Two interim conclusions follow: (1) corporate governance forms part of a larger regulatory framework which is constantly under pressure of being adapted at the domestic and, increasingly, transnational level to the capabilities of global investors and capital flows; and (2) any assessment of the involvement and role of employees in the firm has to be made with this complex background and framework in mind.

The following observations provide a few examples in support of the above two statements. The second section will address the current state of research into employee involvement in the firm from a comparative perspective and argue how issues of employee involvement are being shaped by contemporary developments in corporate governance. The next section will study in more detail the case of German co-determination in order to show how a long-held misconception is applied to what is and what is not 'bad' co-determination in German companies. It will also place

Granovetter, 'The Impact of Social Structure on Economic Outcomes', $19 \mathrm{~J}$. Econ. Persp. (2005) p. 33). Critical of the concept is Jens Beckert, The Great Transformation of Embeddedness: Karl Polanyi and the New Economic Sociology, Max Planck Institute for the Study of Societies, Discussion Paper 07/1 (2007), who reads ‘The Great Transformation' as ‘as a social theory' and argues that a focus on networks fails to appreciate the more complexly structured market as framework of economic activity, on the one hand, and to address Polanyi's concern with the consequences for 'social order and political freedom when economic exchange is organized chiefly through selfregulating markets', on the other. Ibid., at p. 17.

2 Sanford M. Jacoby, The Embedded Corporation: Corporate Governance and Employment Relations in Japan and the United States (Princeton, Princeton University Press 2004). 
this discussion in the context of current EU law-making in the area of corporate governance. The fourth section, then, will suggest an alternative perspective on employee involvement in the firm, one primarily informed by insights provided by management studies, organisational science and scholars of historical political economy. These scholars suggest a differentiated understanding of the firm, where managerial success and economic performance depend on a set of institutional features inside and outside of the firm, encompassing communication and the creation and dissemination of knowledge between different levels of employees ${ }^{3}$ and between the firm and societal knowledge actors. Couched in a vivid culture of incentive structures and adaptation techniques, which enhance collaborative efforts, experimenting and learning, the corporation can thus be seen as an integral part of a highly differentiated knowledge society.

\section{The political economy of corporate governance}

Research into the role and involvement of employees in the contemporary business corporation, be it a small-scale, domestically or regionally operating enterprise or a large multinational corporation, reflects the larger trends in corporate governance and business organisation. We can differentiate between a human resources approach and a co-determination or control approach. The latter has been the much discussed model of German corporate governance, about which we will speak later in more detail. The former can be found, expressed in a very strong form, in Japanese corporate law and, in a weaker form, in the US corporate form. Co-determination comprises different forms of employee involvement in the management of the company. In contrast, a model focusing on human resources, can unfold without granting workers substantive input into management issues of the firm. Japanese corporate governance was hailed all throughout the 1980s as a model nurturing stable employments, skills training and intra-firm mobility. ${ }^{4}$ The human resources manager would

3 Granovetter (1985), loc. cit. n. 1, at p. 501: 'When many employees have long tenures, the conditions are met for a dense and stable network of relations, shared understandings, and political conditions to be constructed.'

4 See, e.g., Mark J. Roe, 'Some Differences in Corporate Structure in Germany, Japan, and the United States', 102 Yale. L. J. (1993) p. 1927. With a view to 
regularly be part of the firm's managerial cohort, given that employee well-being and the preservation of stable employment relations ranked high on the Japanese corporate governance agenda. By comparison, in the United States, human resources have not been considered a crucial or vital element of corporate governance. Human resources managers regularly take second or third place after strategic and, more recently, financial management personnel. The US model can probably best be understood as a 'market model', while for the Japanese one the label 'organisational model' appears most suitable. ${ }^{5}$ There is certainly a whole host of elements and issues connected with such a characterisation, and this should already indicate that any such label hardly captures the complexity of how decisions are taken in and for the business enterprise. Even less can such labels fully illustrate the wealth of elements conducive to sustained economic success. It is here, where business historians, economists, and corporate governance scholars ${ }^{6}$ have much to say to all those who perhaps too quickly assume the triumph of a certain organisational paradigm. ${ }^{7}$

the changing dynamics of the political economy of such regulations, see Luke Nottage, 'Japanese Corporate Governance at a Crossroads: Variation in Varieties of Capitalism', 27 North Carolina Journal of International Law and Commercial Regulation (2001) p. 255; Luke Nottage, 'Nothing New in the North-East? Interpreting the Rhetoric and Reality of Japanese Corporate Governance', 2 CLPE Research Paper Series (2007), available at: $<$ http://www.comparativeresearch.net>; William Lazonick, 'The Japanese Economy and Corporate Reform: What Path to Sustainable Prosperity?', in William Lazonick and Mary O’Sullivan, eds., Corporate Governance and Sustainable Prosperity (London/Basingstoke, Palgrave MacMillan 2002) p. 226.

5 Ibid., at p. 11.

6 See, Mary O’Sullivan, Contests for Corporate Control: Corporate Governance and Economic Performance in the United States and Germany (Oxford, Oxford University Press 2000); Mary O'Sullivan, 'The innovative enterprise and corporate governance', 24 Cambridge Journal of Economics (2000) p. 393; Oliver E. Williamson, 'The Modern Corporation: Origins, Evolution, Attributes', 19 J. Econ. Lit. (1981) p. 1537; William Lazonick, 'Innovative Enterprise and Historical Transformation', 3 Enterprise \& Society (2002) p. 3; Antoine Rebérioux, 'The end of history in corporate governance? A critical appraisal', Amsterdam Research Centre for Corporate Governance Regulation, Inaugural Workshop 17-18 December 2004, available at: <http://www.arccgor.nl/uploads/File/Reberioux\%20Amsterdam\%202.pdf>;

Friedrich Kübler, 'A Shifting Paradigm of European Company Law?', 11 
As can be observed over the last fifteen years, the German codetermination model and the Japanese human resources model have come under pressure. First and foremost, global financial liquidity and the ever shorter periods over which a company's economic performance is being assessed seem to leave little room for the long-term orientation that both German $^{8}$ and Japanese ${ }^{9}$ firms have long been endorsing. This development has been taken by many to reflect on a fundamental convergence of corporate governance regimes. To explore the validity and the lessons from such a finding, we need to place these contentions in the context of comparative assessments of legal structures and their larger institutional, political, economic and cultural environment.

\subsection{Le regard d'autrui: comparative perspectives on company law}

The alleged convergence of corporate governance regimes around the world has been on the mind of investors, policy-makers and scholars for some years now. ${ }^{10}$ In fact, whether such a convergence is actually taking

Colum. J. Eur. L. (2005) p. 219 at pp. 239-240: 'But the complex rules and cumbersome and lengthy procedures are the result of political compromises, which are very much shaped by the ideas and assumptions of the past; they show specific features of "path-dependence" and the stickiness of wellestablished institutional arrangements.'

7 Henry Hansmann and Reinier Kraakman, 'The End of History for Corporate Law', 89 Geo. L. J. (2001) p. 439.

8 Klaus J. Hopt, 'Corporate Governance in Germany', in Klaus J. Hopt and Eddy Wymeersch, eds., Capital Markets and Company Law (Oxford, Oxford University Press 2003) p. 289.

9 Nottage (2001), loc. cit. n. 4.

10 See, e.g., the contributions in Joseph A. McCahery, Piet Moerland, Theo Raaijmakers and Luc Renneborg, eds., Corporate Governance Regimes: Convergence and Diversity (Oxford, Oxford University Press 2002); Jeffrey N. Gordon and Mark J. Roe, eds., Convergence and Persistence in Corporate Governance (Cambridge, Cambridge University Press 2004). A recent publication laudably takes a more contextual approach and features a comprehensive section on regulatory structures, bureaucracy and administrative law: see Klaus J. Hopt, Eddy Wymeersch, Hideki Kanda and Harald Baum, eds., Corporate Governance in Context: Corporations, States 
place has at the same time been contested by many participants in the debate. ${ }^{11}$ The trickiness of such assessments of a moving target is certainly also felt by such a keen observer as The Economist, which in a recent survey on 'European Business' swayed between dismissal of the European way of doing things, on the one hand, and Europe's promise to pull through, on the other. ${ }^{12}$ Vice Chancellor Leo Strine, Jr. noted an abundance of 'tired features' in the 'so-called corporate governance debate. 'Exaggeration is the norm; conversation the exception.'13

At the outset of any assessment of converging regulatory regimes should lie an appreciation of what it is that is allegedly converging. In

and Markets in Europe, Japan and the US (Oxford, Oxford University Press 2005).

11 See, e.g., Sigurt Vitols, 'Varieties of Corporate Governance: Comparing Germany and the UK', in Peter E. Hall and David W. Soskice, eds., Varieties of Capitalism: The Institutional Foundations of Comparative Advantage (Oxford, Oxford University Press 2001) p. 337; Sally Wheeler, Corporations and the Third Way (Oxford, Hart 2002); Wolfgang Streeck, 'German Capitalism: Does it Exist? Can it Survive?', in Colin Crouch and Wolfgang Streeck, eds., Political Economy of Modern Capitalism (London, SAGE 1997) p. 33; Ronald Dore, William Lazonick and Mary O'Sullivan, 'Varieties of Capitalism in the Twentieth Century', 15 Oxford Review of Economic Policy (1999) p. 102. See also the contributions in Wolfgang Streeck and Kozo Yamamura, eds., The Origins of Nonliberal Capitalism (Ithaca, Cornell University Press 2001); and Kozo Yamamura and Wolfgang Streeck, eds., The End of Diversity? Prospects for German and Japanese Capitalism (Ithaca, Cornell University Press 2003). Harald Baum, 'Change of Governance in Historic Perspective: The German Experience', in Hopt et al., op. cit. n. 10, available at: <http://ssrn.com/abstract=695741 $>$, observes that a 'gradual and partial de-bundling of the corporatist "Deutschland AG" appears to be somewhat probable.' Ibid., at p. 21. See also Kübler, loc. cit. n. 6, at p. 239: 'slow, piecemeal, cumbersome' changes of corporate law structures in Europe.

12 'Who are the Champions?', The Economist, 8 February 2007, available at: $<$ http://www.economist.com/surveys/displayStory.cfm?story id=8621685 $>$.

13 Leo E. Strine Jr., 'Toward Common Sense and Common Ground? Reflections on the Shared Interests of Managers and Labor in a More Rational System of Corporate Governance', The Dorsey and Whitney Foundation Lecture, 10 March 2007, forthcoming in J. Corp. Law (2007) p. 3, available at: $<$ http://ssrn.com/abstract $=989624>$. 
other words, we need to be clear on what we mean by corporate governance and which aspects of it we currently see changing. Secondly, we need to be mindful that identifying and evaluating current developments necessitates a comparison of not only different systems' formal rules and codifications but also their customs and business practices. In other words, we need to compare the law on the books and the law in action. The latter, certainly in the area of corporate governance, constitutes a wide-ranging variety of informal rules, standards, codes of conduct and understandings of relevant business communities. While these form an integral part of a vibrant legal and economic environment, they are much harder to identify and ascertain by an outside observer.

In this light, I would like to suggest that we attempt our comparison of existing corporate governance regimes through a combination of traditional modes of comparative law, that is to say, its instruments, norms and their functionality, on the one hand, ${ }^{14}$ and the political economy of corporate governance, in particular the mix of formal and informal, of hard and soft laws, rules, standards and practices, on the other. ${ }^{15}$ This combination will allow us to appreciate the real changes that are taking place in different corporate law regimes around the world. In addition, such a perspective will allow us to gain a deeper understanding of the currently unfolding trends of convergence and divergence between corporate governance regimes in regional markets and regulatory spaces such as the European Union. Here, for example, the particular history of corporate law harmonisation cannot be properly understood without such a 'deeper reading' of the hard-soft forms of corporate law development that are characterising contemporary changes in the existing regulatory regimes. ${ }^{16}$ The European scene for corporate law-making, then, is a

14 See only Ralf Michaels, 'The Functional Method in Comparative Law', in Mathias Reimann and Reinhard Zimmermann, eds., Oxford Handbook of Comparative Law (Oxford, Oxford University Press 2006) p. 339.

15 Peer Zumbansen, 'Spaces and Places: A Systems Theory Approach to Regulatory Competition in European Company Law’, 12 Eur. L. J. (2006) p. 534, available at: $<\underline{\text { http://ssrn.com/abstract }=902695}>$.

16 Simon Deakin, 'Reflexive Governance and European Company Law,' CLPE Research Paper Series (2007), available at: <http://www.comparativeresearch.net>; Peer Zumbansen, 'The Parallel Worlds of Corporate Governance and Labor Law’, 13 Indiana Journal of 
remarkable laboratory for the study of multilevel and multipolar lawmaking in a politically and culturally contested arena, where different historically grown and embedded political economies are colliding. ${ }^{17}$

\subsection{What is corporate governance?}

Confusion over the potential impact of the alleged convergence in different corporate governance regimes is what lies at the heart of what we mean by 'corporate governance'. The law of corporate governance, commonly conceived as 'company law', 'corporate law' or 'business associations', is embedded in a larger regulatory scene that also comprises fields such as securities regulation, labour law, industrial relations and insolvency law. But these legal fields are complemented by a set of institutions that structure the development and practice of corporate governance. Building on the work of Karl Polanyi in the 1940s, ${ }^{18}$ economic sociologists focus on the 'embeddedness' of economic action and have been providing a plethora of intriguing case studies and analysis ${ }^{19}$ of the 'institutional, cultural and social contexts ${ }^{, 20}$ in which commercial transactions are unfolding. ${ }^{21}$ In order to trace the particular

\footnotetext{
Global Studies (2006) p. 261, available at: $<$ http://ssrn.com/abstract $=902650>$.

17 Martin Rhodes and Bastian van Apeldoorn, 'Capital Unbound? The Transformation of European Corporate Governance', 5 Journal of European Public Policy (1998) p. 406; Vanessa Edwards, 'The European Company Essential Tool or Eviscerated Dream?', 40 Common Market Law Review (2003) p. 443; Peer Zumbansen, 'European Corporate Law and National Divergences: The Case of Takeover Law', 3 Wash. U. Glob. Stud. L. Rev. (2004) p. 867.

18 Polanyi, op. cit. n. 1.

19 Among the most eminent contributions in this regard is Granovetter (1985), loc. cit. n. 1. The Director of the Cologne-based Max Planck Institute for the Study of Societies, Jens Beckert, refers to that article as "the "founding manifesto" of the new economic sociology'. See Beckert, op. cit. n. 1, at p. 6.

20 Beckert, op. cit. n. 1, at p. 16.

21 See Hartmut Berghoff, 'Markterschließung und Risikomanagement', 92 Vierteljahreschrift für Sozial- und Wirtschaftsgeschichte (2005) p. 141; Richard Whitley, 'The Institutional Structuring of Innovation Strategies:
} 
characteristics of distinct national systems of corporate governance, it is essential to cast light on the historical, socio-economic and legal developments that have contributed to national variation. While there is an important body of literature underlining the relevance of historical trajectories and the associated competitive advantages of national differences (the so-called 'varieties of capitalism' school ${ }^{22}$ ), there is a wide agreement that these distinct national systems are under severe and growing pressure towards convergence. The privatisation of public welfare systems and the increased tendency to base pension and retirement financing on the capital market ${ }^{23}$ have coincided with a worldwide competition for stock market investments. ${ }^{24}$ As a consequence, the capacity of traditional stakeholder-oriented systems of corporate governance to provide the transparency and management control that is

Business Systems, Firm Types and Patterns of Technological Change in Different Market Economies', 21 Organization Studies (2000) p. 855; William Lazonick, 'Varieties of Capitalism and Innovative Enterprise', 24 Comparative Social Research (2007) p. 21.

22 Peter A. Hall and David W. Soskice, 'An Introduction to Varieties of Capitalism', in Hall and Soskice, op. cit. n. 11, at p. 1; David Soskice, 'Divergent Production Regimes: Coordinated and Uncoordinated Market Economies in the 1980s and 1990s', in Herbert Kitschelt, Peter Lange, Gary Marks and John D. Stephens, eds., Continuity and Change in Contemporary Capitalism (Cambridge, Cambridge University Press 1999) p. 101; Dore, Lazonick and O’Sullivan, loc. cit. n. 11; Robert Boyer, 'Coherence, Diversity, and the Evolution of Capitalisms - The Institutional Complementarity Hypothesis', 2 Evol. Inst. Econ. Rev. (2005) p. 43 at pp. 45-47; see also Matthew Allen, 'The varieties of capitalism paradigm: not enough variety?', 2 Socio-Economic Review (2004) p. 87.

23 Friedrich Kübler, 'The Impact of Equity Markets on Business Organization: Some Comparative Observations Regarding Differences in the Evolution of Corporate Structures', 2 European Business Organization Law Review (2001) p. 669; Friedrich Kübler, 'The Rules of Capital Under Pressure of the Securities Markets', in Hopt and Wymeersch, op. cit. n. 8, at p. 95.

24 Theodor Baums, 'Interview: Reforming German Corporate Governance: Inside a Law-Making Process of a Very New Nature', 2 German Law Journal (2001), available at: <http://www.germanlawjournal.com/past_issues.php?id=43>; $\quad$ Theodor Baums, 'Company Law Reform in Germany', 3 J. Corp. L. Stud. (2003) p. 181. 
necessary for success in the global competition for investments is increasingly contested. $^{25}$

Beyond the disputes over the merits of 'shareholder primacy', however, lies the essential question: the nature of the business corporation itself. $^{26}$ Beyond the ongoing struggle between shareholder- and stakeholderoriented concepts of corporate governance ${ }^{27}$ lies a wide field of research concerning the organisational design of today's corporation as a complex and innovative institution of social learning. ${ }^{28}$ The involvement of workers within the firm is not an issue that can be solely understood against the background of established and hotly contested models of codetermination. $^{29}$ Rather, the role of workers in the firm can itself be

25 Henry Hansmann and Reinier Kraakman, 'Toward a Single Model of Corporate Law?', in McCahery et al., op. cit. n. 10, at p. 56.

26 Simon Deakin, 'Workers, Finance and Democracy', in Catherine Barnard, Simon Deakin and Gillian S. Morris, eds., The Future of Labour Law: Liber Amicorum Bob Hepple (Oxford, Hart 2003) p. 79.

27 Richard Mitchell, Anthony O’Donnell and Ian Ramsay, 'Shareholder Value and Employee Interests: Intersections between Corporate Governance, Corporate Law and Labour Law' (2005), available at: $<$ http://cclsr.law.unimelb.edu.au/researchpapers/Shareholder\%20value\%20paper\%20_23.06.05_.pdf>.

28 Karl-Heinz Ladeur, 'Die Prozeduralisierung des Unternehmens', in Dieter Hart, ed., Privatrecht im 'Risikostaat' (Baden-Baden, Nomos 1997) p. 137; Irene Lynch Fannon, Working Within Two Kinds of Capitalism: Corporate Governance and Employee Stakeholding: US and EC Perspectives (Oxford, Hart 2003); James E. Post, Lee E. Preston and Sybille Sachs, Redefining the Corporation: Stakeholder Management and Organizational Wealth (Stanford, Stanford Business Books 2002); Antoine Pirovano, 'La "boussole” de la société. Intéret commun, intéret social, intéret de l'entreprise', Recueil Dalloz (1997) p. 189; Michel Crozier, L'entreprise à l'écoute. Apprendre le management post-industriel [Paris, Interéditions 1989] (Points 1994) [REFERENCE UNCLEAR ???]; Peer Zumbansen, 'The Conundrum of Corporate Social Responsibility: Remarks on the Changing Nature of Firms and States', in Rebecca M. Bratspies and Russell A. Miller, eds., Transboundary Harm: Lessons from the Trail Smelter Arbitration (Cambridge, Cambridge University Press 2006) p. 274; Lazonick, loc. cit. n. 21.

29 See, e.g., Jens Dammann, 'The Future of Codetermination after Centros: Will German Corporate Law Move Closer to the U.S. Model?', 8 Fordham 
explained only with regard to the ways in which the firm is organised to generate, channel and process fragmented knowledge and innovative capacity. ${ }^{30}$ The association of workers' involvement with a firm's social, ${ }^{31}$ intellectual and innovative capital certainly differs from the hitherto held perception that workers' involvement in corporate governance is merely an inefficient check on shareholder power. In fact, switching from a conflict model, which opposes shareholders against employees, to one of cooperation and integration of viewpoints, capacities and processes opens up a new perspective on workers' involvement. This perspective is directed at the productive input of workers' knowledge for a more

Journal of Corporate \& Financial Law (2003) p. 607; Anja Strüve, 'Deutscher Juristentag 2006', 1 Legal Latitudes (2007) p. 4 at p. 5, available at: <www.osgoode.yorku.ca/legallatitudes $>$. From the ongoing vivid German discussion, see - for a conciliatory viewpoint - Thomas Raiser, Unternehmensmitbestimmung vor dem Hintergrund europarechtlicher Entwicklungen. Gutachten B zum 66. Deutschen Juristentag, Stuttgart 2006 (Munich, Beck 2006) pp. B 111-116; Walter Bayer, 'Auswirkungen der Niederlassungsfreiheit nach den EuGH-Entscheidungen Inspire Art und Überseering auf die deutsche Unternehmensmitbestimmung', 49 Die Aktiengesellschaft (2004) p. 534 at pp. 537-538. In contrast, see Michael Adams, 'Das Ende der Mitbestimmung', 27 Zeitschrift für Insolvenzpraxis (2006) p. 1561; Martin Hennsler, 'Bewegung in der deutschen Mitbestimmungsdiskussion - Reformdruck durch Internationalisierung der Wirtschaft', Recht der Arbeit (2005) p. 330; Eberhard Schwark, 'Globalisierung, Europarecht und Unternehmensmitbestimmung im Konflikt', 49 Die Aktiengesellschaft (2004) p. 173. With a call not for abandonment but for reform from a particular focus on the organisational structures within the company, on the one hand, and the firm's overall competitiveness based on business strategy and product quality, on the other: Axel von Werder, 'Überwachungseffizienz und Unternehmensmitbestimmung', 49 Die Aktiengesellschaft (2004) p. 166.

30 Antoine Rebérioux, 'Les marchés financiers et la participation des salariés aux décisions', 93 Travail et Emploi (2003) p. 25; Antoine Rebérioux, 'European Style of Corporate Governance at the Crossroads: The Role of Worker Involvement', 40 Journal of Common Market Studies (2002) p. 111; Whitley, loc. cit. n. 21, at p. 864.

31 See Ian Jones, Michael Pollitt and David Bek, 'Multinationals in their Communities: A Social Capital Approach to Corporate Citizenship Projects' (2006), available at: <http://www.cbr.cam.ac.uk/pdf/WP337.pdf>. 
efficient governance of the firm. ${ }^{32}$ The latter differs from the muchdiscussed and often not sufficiently understood form of co-determination as it exists, for example, in German supervisory boards. ${ }^{33}$ In these, half of the board's members are employee representatives. This has led many observers to a harsh dismissal of this powerful influence of workers. The fact remains, however, that the chairman of the supervisory board, usually a shareholder representative, holds the deciding vote. The confusion about the parity of powers in the supervisory board is legendary. While the fact of the chairman's deciding vote alone should put overly troubled minds to rest about the purportedly counterproductive effects of co-determined supervisory boards of large German enterprises, even recent empirical evidence from German companies indeed seems to suggest that many managers recognise benefits from the - still - existing system. ${ }^{34}$

In contrast, the other form of co-determination, which has always existed in the shadow of the internationally discussed and scrutinised board co-determination, concerns so-called works councils. These can be formed in all companies with at least five employees, if at least three have been with the firm for six months.

Works councils are constituted only by employees and are elected by secret ballot. They are understood as being a counterpart to management and play a crucial role in the firing process, seeking together with management to maintain socially justifiable criteria when selecting personnel to be laid off. This form of worker involvement, from an international perspective, has existed in a quiet, neglected corner of the otherwise heated corporate governance debate. While the law clearly

32 Ash Amin and Patrick Cohendet, Architectures of Knowledge: Firms, Capabilities and Communities (Oxford, Oxford University Press 2004) p. 113: "The first and most obvious "management" step implicit in a model of learning by doing is clear recognition of the limits of management by design, of the top-down inculcation of creativity.'

33 For a concise presentation of the model, see only Katharina Pistor, 'Codetermination: A Sociopolitical Model with Governance Externalities', in Margaret M. Blair and Mark J. Roe, eds., Employees and Corporate Governance (Washington, DC, Brookings Institution Press 1999) p. 163.

34 Martin Höpner, 'Mitbestimmungskritik hält Prüfung nicht stand', 6 Mitbestimmung (2004) pp. 54-57, available at: <http://www.mpi-fgkoeln.mpg.de/people/mh/paper/MB_6-2004.pdf>. 
attributes a relatively prominent role to works councils, their institutional success has been varied. ${ }^{35}$ Only recently, works councils have acquired a more positively regarded currency. One of the reasons for this development was the 1994 introduction of so-called European Works Councils. ${ }^{36}$ Their success has been ambiguous at best, assessments ranging from doubts over unions pursuing their local interests through the newly established $\mathrm{EWCs}^{37}$ and critical evaluations of the less-empowered EWCs when compared to the German Betriebsräte ${ }^{38}$ to a sceptical rejection of EWCs as yet another mosaic stone in an already losing battle for organised labour interests. ${ }^{39}$ While these developments unfolded at the European level, domestically works councils became increasingly entangled in pressure systems created by firm management, on the one hand, and trade unions, on the other. While the latter eventually conceded so-called opening clauses that would allow variations to the collective agreement to be stipulated at the firm level, management has taken this opportunity in recent years to forcefully push employees to enter into unfavourable agreements in exchange for, say, job security. Effectively, works councils can now often be seen to accept agreements that contain standards that are well below the threshold contained in collective agreements. Trade unions themselves find themselves facing the dilemma that their protest would potentially drive more of their already weakening members away. ${ }^{40}$

Taking a step back from this labour interests perspective, however, we can identify a set of other considerations relating to the works councils. Here, then, another reason for the increased attention received by works

35 Manfred Weiss, 'Labor Law', in Joachim Zekoll and Mathias Reimann, eds., Introduction to German Law (The Hague, Kluwer Law International/Munich, Beck 2006) p. 299 at pp. 311-312.

36 Paul Marginson, Mark Hall, Aline Hoffmann and Torsten Müller, 'The Impact of European Works Councils on Management Decision Making in UK and US-based Multinationals: A Case Study Comparison', 42 British Journal of Industrial Relations (2004) p. 209.

37 Bob Hancké, 'European Works Councils and Industrial Restructuring in the European Motor Industry', 6 Eur. J. Ind. Rel. (2000) p. 35.

38 Wolfgang Streeck, 'The Internationalization of Industrial Relations in Europe: Prospects and Problems’, 26 Politics \& Society (1998) p. 429.

39 Thorsten Schulten, 'European Works Councils: Prospects for a New System of European Industrial Relations', 2 Eur. J. Ind. Rel. (1999) p. 303.

40 Weiss, loc. cit. n. 35, at p. 319. 
councils can be seen in the overwhelming pressure on firms to improve their competitiveness (inseparable from their organisational structure), the firms' location and the applicable laws governing salaries, production and social costs. In this context, works councils are increasingly being recognised as essential fora for the much-needed negotiation between management and employees in developing and realising the most costeffective solutions for the firm's future. ${ }^{41}$ A crucial aspect, then, is that, at the same time as the influence of trade unions is diminishing, works councils might be seen as enforcing their own demise instead of being able to work against it. In this light, works councils can be seen to be entering a pact with the devil. Where agreements between management and employees that are pursued as part of industrial restructuring strategies on the part of management in highly competitive industries can be reached at the level of the firm, ${ }^{42}$ the larger framework of workers' representation in a coordinated market becomes economy questionable. In reality, management can exercise a large degree of pressure on works councils by connecting demands on lower wages, longer working hours and so on with threats of relocation, plant closure and the like - all that in exchange for job security, for the time being. ${ }^{43}$

This problematic interaction between management and works councils certainly does not invite a very optimistic view on management-employee relations. To be sure, it is not the fact that there is such interaction that is problematic but the reduction of the works council to a transmission belt that communicates the management's will to the employee constituency. In this scenario, chances might remain unused for a resource-based, fruitful and sustained collaboration between the different power levels within the corporation.

This last aspect is important. As indicated, there is a second reason for the recent interest in works councils. In fact, this reason provides a much more positive perspective on the interaction among the different powers within the firm. Organisational science scholars and management theorists

41 Joel Rogers and Wolfgang Streeck, eds., Works Councils: Consultation, Representation, and Cooperation in Industrial Relations (London, University of Chicago Press 1996).

42 Hancké, loc. cit. n. 37, at p. 39.

43 Weiss, loc. cit. n. 35, at p. 319. 
have been emphasising the economic gains that can result from close cooperation between management and the firm's work force. The value of workers' input in refining, strengthening and consolidating the firm's performance is increasingly recognised in traditionally organised firms and to a certain degree also in more loosely organised, unbundled or networked firms. The latter has been described by organisation and labour scholars as the final deadly blow delivered to workers' rights, given that organising becomes more difficult as the firm becomes more decentralised, as the organisational structure becomes more opaque and employment relations become more precarious. The combination of corporate organisation in the twenty-first century firm and the flexibilisation of work constitutes the dark side of the culture of the new capitalism. ${ }^{44}$ At the same time, the very volatility of corporate organisation in a networked economy must not necessarily lead only to a further erosion of workers' power within a firm. More sophisticated studies by management and organisation theorists show that management in many cases relies on a healthy and functioning relationship with the firm's employees, especially where high profile and fast-changing organisational patterns require capacities of adaptation and responsiveness. ${ }^{45}$

As an interim observation, we can say that co-determination exists in two forms, one involving quasi-parity of shareholder and employee representatives on the supervisory board of large stock corporations and the other one involving works councils in small to large firms. The first form has regularly attracted a lot of international attention and has recently attracted strong criticism as constituting a so-called 'competitive disadvantage' in the global race for investment. And yet, a closer look at the voting structures of the board, together with the deliberation practices long followed by corporate actors in Germany, reveals - as we saw above - the myth behind the much-discussed German social model, of which codetermination has always been seen as a central pillar. ${ }^{46}$ The latter model, located in works councils, has only more recently stepped forward to play a remarkably differentiated role. On the one hand, works councils have become the site for the implementation of management policy concerning

44 Richard Sennett, The Culture of the New Capitalism (New Haven, Yale University Press 2006).

45 Jones, Pollitt and Bek, loc. cit. n. 31.

46 Streeck, loc. cit. n. 11 , at p. 37. 
restructuring, plant relocation and closing. On the other, works councils could come to be seen as potentially important players in tapping, structuring and realising knowledge and capacity pools that exist within the firm. The latter, more positive perspective on workers' involvement in the firm provides a friendly contrast to the before-mentioned development.

\section{The global and the local: spaces and places of convergence and divergence}

The following section will place these observations into the context of the contemporary corporate law-making environment in the European Union and Germany (in particular with a view to complementing official rules with unofficial ones such as soft norms, recommendations and codes of conduct). Before this, however, it is necessary to allude briefly to the larger conceptual framework in which these developments have been taking place. Today, contemporary global developments demand the attention of domestic law reformers in the areas of corporate law and securities regulation. There are different ways, in which national governments or, in the case of the European Union, regional lawmakers, have been reacting to international developments. The post-Cold War opening of formerly closed markets, along with the large-scale restructuring of publicly financed services and infrastructures and their replacement by privatisation and deregulation, has fundamentally altered the playing field for business corporations, investors and interest groups, as well as for domestic and transnational regulators.

Table 1: The End(s) of History

END OF HISTORY I

Francis Fukuyama 1992: End of History

Michel Albert 1991: Capitalisme contra Capitalisme

END OF HISTORY II

Hall/Soskice 2001: Varieties of Capitalism

Hansmann/Kraakman 2001: End of History in Corporate Law 
To trace how these global developments translate in a domestic and a regional context, the following subsection will take a closer look at both the EU company law scene and the corporate law reform process currently taking place in Germany.

\subsection{Germany's company law reform and changing regulatory landscapes}

The 1980s and 1990s in Germany were a period of difficult bargaining between a pro-shareholder government and deeply entrenched stakeholders, unions and lobby groups. With the end of Social Democratic government in 1982, the Christian Democratic/Liberal majority took power in 1983. In 1998, at the end of Christian Democratic rule, the first major corporate law reform legislation since the 1960s was finally adopted. The Law on Corporate Control and Transparency (KonTraG) introduced a number of elements designed to improve German corporate governance, long criticised for its less developed disclosure rules and, importantly, for its already mentioned two-tier board, in which worker representatives have half the seats on the supervisory board - but as we have seen - not half the votes, as the chairman, a shareholder representative, has the deciding vote.

The KonTraG left this structure untouched, as well as the high number of seats on the supervisory board, and thereby failed to satisfy longstanding demands to change the German system and make the supervisory board more effective. ${ }^{47}$ The German debate concerning the reform of the supervisory board has not lost in intensity and has indeed

47 For an excellent discussion of these changes, see only John W. Cioffi, 'Restructuring "Germany Inc.": The Politics of Corporate Governance Reform in Germany and the European Union', 24 Law \& Policy (2002) p. 355; John W. Cioffi, 'Corporate Governance Reform, Regulatory Politics, and the Foundations of Finance Capitalism in the United States and Germany', 7 German L. J. (2006) p. 533. 
received renewed input from a combination of forces both at the domestic and the transnational and European level.

Domestic corporate law reform discussions such as those in Germany ${ }^{48}$ or in other countries ${ }^{49}$ are takingplace in the light of a European and global debate over competition for mobile capital and how corporate law systems might accommodate companies' needs to tap into these capital markets without boundaries. ${ }^{50}$ At the same time, the debate is taking place against the background of a complex European integration process in which the political and cultural outcome remains unsettled. ${ }^{51}$

It is obvious that, within the European Union, the varieties of capitalism approach is of great significance, for it explicitly addresses the embedded, historically grown socio-political and cultural systems of the Member States. ${ }^{52}$ How difficult it would be to achieve any harmonisation of company law standards in Europe given the high degree of diversity of existing company law regimes was strongly evidenced by the decadeslong struggle over the European Company, originally initiated as early as

48 See, e.g., Baums (2003), loc. cit. n. 24; Ulrich Seibert, 'The Company Law Reform Projects of the German Ministry of Justice', 69 Rabels Zeitschrift für ausländisches und internationales Privatrecht (2005) p. 712; Ulrich Noack and Dirk Zetzsche, 'Corporate Governance in Germany: The Second Decade', Center for Business and Corporate Law (CBC) Research Paper Series (2005).

49 Guido Ferrarini, Paolo Guidici and Maria Stella Richter, 'Company Law Reform in Italy: Real Progress?’, 69 Rabels Zeitschrift für ausländisches und internationales Privatrecht (2005) p. 658; Eilís Ferran, 'The Company Law Reform in the United Kingdom: A Progress Report', ibid., pp. 629-657; Michel Menjucq, 'The Company Law Reform in France', ibid., pp. 698-711; Claude Champaud and Didier Danet, 'NRE', Revue trimestrielle de droit commercial e de droit économique (2002) p. 17.

50 See the contributions in Steven Weber, ed., Globalization and the European Political Economy (New York, Columbia University Press 2001).

51 Joseph H.H. Weiler, 'The Transformation of Europe', 100 Yale L. J. (1991) p. 2403; Fritz W. Scharpf, Governing Europe: Effective and Democratic? (Oxford, Oxford University Press 1999); Christian Joerges, 'The Law's Problems with the Governance of the European Market', in Christian Joerges and Renaud Dehousse, eds., Good Governance in Europe's Integrated Market (Oxford, Oxford University Press 2002) p. 3; Christoph Möllers, 'European Governance: Meaning and Value of a Concept', 43 Common Market Law Review (2006) p. 313.

52 Hall and Soskice, op. cit. n. 11. 
the 1970s and adopted after many compromises in 2001. ${ }^{53}$ Another example of the European varieties of capitalism in the field is the almost fifteen-year-long fight over a European Takeover Directive. This was concluded only in 2004, resulting in a directive that contains so many optout clauses, that the question has been asked whether it has led to any harmonisation at all. ${ }^{54}$

International attention is usually attracted by the noise that surrounds the larger developments, such as European directives or the corporate governance standards promulgated by international bodies such as the OECD (Organisation for Economic Cooperation and Development) or by domestic legislators (such as the US Sarbanes Oxley Act in 2002). Less attention is focused on the dramatically more complex forms of law reform that take place at other levels and are not so easily discernable by the outside spectator. Examples of such reforms can be found within the myriad ways in which Member States move to implement European law into their domestic legal orders. While there are straightforward and easy ways to track reforms, as for example when a Member State passes a law that appears to translate a European directive into its domestic legal framework, in reality such law-making processes take very different forms within hotly contested fields. In short, they take place in many unofficial, harder to trace ways, as the landscape of norm making in corporate law (as in many other areas) has been changing dramatically. The emergence of privately made best practice guidelines, codes of conduct and corporate governance codes has led to a far-reaching change of the relevant regulatory landscape in which companies operate today. ${ }^{55}$ But many of its

53 Erik Werlauff, 'The SE Company - A New Common European Company from 8 October 2004', 14 European Business Law Review (2003) p. 85; Christoph Teichmann, 'The European Company - A Challenge to Academics, Legislatures and Practitioners', 4 German L. J. (2003) p. 309.

54 Christian Kirchner and Richard W. Painter, 'Takeover Defenses under Delaware Law, the Proposed Thirteenth EU Directive and the New German Takeover Law: Comparison and Recommendations for Reform', 50 American Journal of Comparative Law (2002) p. 451; Zumbansen, loc. cit. n. 17.

55 Ben Pettet, 'Combined Code: A Firm Place for Self-Regulation in Corporate Governance', 13 Journal of International Banking Law (1998) p. 394; Baums (2001), loc. cit. n. 24; Peer Zumbansen, 'The Privatization of Corporate Law? Corporate Governance Codes and Commercial Self-Regulation', Juridikum (2002) p. 136; Johannes Köndgen, 'Privatisierung des Rechts. Private 
features and elements are not - and arguably cannot - be truthfully represented and documented in the official legislation. The proliferation of private, semi-public and quasi-public lawmakers in the fields of corporate and securities law has altered the regulatory landscape so that it has become much harder to develop a political critique of the processes as they unfold. In corporate law, this is expressed by corporate governance codes and best practice recommendations, as it is in the case of labour law by codes of conduct, which purport to provide for a comprehensive regulation of employment relationships. ${ }^{56}$ To be sure, the shift away from traditional forms of law-making and the embrace of myriad ways of norm creation (often summarised as 'governance') has had as one of its consequences the highly problematic removal of many regulatory changes from the political debate. In many cases, 'demands' of the market are offered as sufficient justifications for legal change, effectively moving it outside of the political arena of deliberation and contestation.

Illustrating this point are the deep-reaching changes to that element of German corporate governance that seems to be at the core of the 'end of history' critique of Germany's need for reform, on the one hand, and of Mark Roe's characterisation of 'social democratic' corporate governance, on the other. ${ }^{57}$ The here found depiction of the allegedly social democratic

Governance zwischen Deregulierung und Rekonstitutionalisierung', 206 AcP (2006) p. 477.

${ }^{56}$ For a critique, see Harry W. Arthurs, 'Private Ordering and Workers' Rights in the Global Economy: Corporate Codes of Conduct as a Regime of Labour Market Regulation', in Joanne Conaghan, Richard Michael Fischl and Karl Klare, eds., Labour Law in an Era of Globalization. Transformative Practices and Possibilities (Oxford, Oxford University Press 2002) p. 471; Adelle Blackett, 'Codes of Corporate Conduct and the Labour Law Regulatory State in Developing Countries', in John J. Kirton and Michael J. Trebilcock, eds., Hard Choices, Soft Law: Voluntary Standards in Global Trade, Environment and Social Governance (Aldershot, Ashgate 2004) p. 121; Zumbansen, loc. cit. n. 16.

${ }^{57}$ Roe, loc. cit. n. 4; Mark J. Roe, 'German Co-Determination and German Securities Markets', in Klaus J. Hopt, Hideki Kanda, Mark J. Roe, Eddy Wymeersch and Stefan Prigge, eds., Comparative Corporate Governance: The State of the Art and Emerging Research (Oxford, Clarendon Press 1998) p. 361; Mark J. Roe, Political Determinants of Corporate Governance (Oxford, Oxford University Press 2003). 
origins, nature and preservation of workers' co-determination on company boards may, however, blind our view to the much more nuanced, ambiguous and multi-directional lines along which corporate governance has been evolving.

Indeed, one of the most discussed features of German company law co-determination - has been attracting scathing criticism from the press, both from lobbyists who fear the negative signal co-determination sends to prospective and much needed international investors and from scholars. ${ }^{58}$ Even the national lawyers' meeting in the autumn of 2006 put codetermination on the agenda and openly explored its possible demise. ${ }^{59}$ These developments strongly suggest that even in Germany, one of the heartlands of Michel Albert's Rhenish capitalism, ${ }^{60}$ there is a shift towards a more shareholder-driven corporate governance regime. ${ }^{61}$

However, what the bird's eye view of the observer fails to capture is the altogether ambivalent process - both politically and institutionally that characterises German company law reform. Here, the point is that the legal reform agenda is driven by an intricate and, for German traditions, seemingly unprecedented combination of official and unofficial lawmaking. ${ }^{62}$ The currently pursued reform agenda is the result of federal

58 See references supra $\mathrm{n} .21$.

60 Michel Albert, Capitalisme contre Capitalisme (Paris, Editions du Seuil 1991).

61 See Cioffi (2006), loc. cit. n. 47.

62 See the increasing number of scholarly assessments of this process: Peter Hommelhoff and Martin Schwab, 'Staats-ersetzende Privatgremien im Unternehmensrecht', in Walter Drenseck and Roman Seer, eds., Festschrift für Heinrich Wilhelm Kruse zum 70. Geburtstag (Cologne, Schmidt 2001) p. 693; Stefan Berg and Mathias Stöcker, 'Anwendungs- und Haftungsfragen zum Deutschen Corporate Governance Kodex', 56 Wertpapiermitteilungen (2002) p. 1569; Marcus Lutter, 'Die Kontrolle der gesellschaftsrechtlichen Organe: Corporate Governance - ein internationales Thema', 24 Jura (2002) p. 83; Christoph H. Seibt, 'Deutscher Corporate Governance Kodex und Entsprechenserklärung ( $\$ 161$ AktG-E)’, 47 Die Aktiengesellschaft (2002) p. 249; Gregor Bachmann, 'Der "Deutsche Corporate Governance Kodex": Rechtswirkungen und Haftungsrisiken', Wertpapiermitteilungen (2002) p. 
law-making and the work of an expert commission that was initiated by the government in $2000 .^{63}$ That commission resulted in the issuance of detailed marching orders, recommendations and demands for the legislator as to how to adapt the German company law system to the 'needs of global financial markets'. ${ }^{64}$ On the other hand, the commission also suggested the creation of a follow-on commission to draft a code of best practices, the so-called German Corporate Governance Code. ${ }^{65}$ An early discussion regarding the Code's legal nature quietly subsided. ${ }^{66} \mathrm{~A}$ comprehensive law reform in corporate law, which was initiated by the Social Democratic government at the time, seems to turn the dearly held cliché of Germany's stakeholder capitalism company law regime on its head. The first and the second commissions, in preparing the legislative design and the collection of best practice guidelines, ingeniously managed to adopt allegedly universal models and terms through which they prepared the field for the major overhaul. But while everybody expected that this would mean the abolition of co-determination, change occurred in

2137; Georg Borges, 'Selbstregulierung im Gesellschaftsrecht - zur Bindung an Corporate Governance-Kodices', 32 ZGR (2003) p. 508.

63 Baums (2001), loc. cit. n. 24; Zumbansen, loc. cit. n. 55.

64 Theodor Baums, ed., Bericht der Regierungskommission Corporate Governance. Unternehmensführung, Unternehmenskontrolle, Modernisierung des Aktienrechts (Cologne, Otto Schmidt 2001).

65 Gerhard Cromme (Chairman), German Corporate Governance Code, drafted by the German Corporate Governance Commission, Berlin, 26 February 2002, available at: <http://www.corporate-governancecode.de/eng/download/CorGov_Endfassung_E.pdf $>$.

66 Martin Wolf, 'Corporate Governance. Der Import angelsächsicher "SelfRegulation” im Widerstreit zum deutschen Parlamentsvorbehalt', 35 Zeitschrift für Rechtspolitik (2002) p. 59; Paul Kirchhof, 'Demokratie ohne parlamentarische Gesetzgebung?’, 54 Neue Juristische Wochenschrift (2001) p. 1332; Wolfgang Seidel, 'Kodex ohne Rechtsgrundlage', Neue Zeitschrift für Gesellschaftsrecht (NZG) (2004) p. 1095; Markus Heintzen, 'Der Deutsche Corporate Governance Kodex aus der Sicht des deutschen Verfassungsrechts', 25 Zeitschrift für Wirtschaftsrecht (2004) p. 1933; Henrik-Michael Ringleb, Thomas Kremer, Marcus Lutter and Axel von Werder, Kommentar zum Deutschen Corporate Governance Kodex (KodexKommentar), 2nd edn. (Munich, Beck 2005) pp. 27-30: arguing that both the Baums Commission and the legislator intended the core of the Code to consist of non-binding recommendations for which no statutory authorisation would be necessary. 
much more subtle, but clearly no less dramatic ways. The government did not openly attack co-determination, while the semi-political, quasi-public expert body - the commission - silently and effectively worked towards its deconstruction. Certainly, the recommendations pertaining to the isolation of the inter-shareholder dialogue from that of the stakeholders (the employees and union representatives) ${ }^{67}$ must be seen within the context of the post-Centros, Überseering and Inspire Art fallout within the European company law scene. ${ }^{68}$ That scene, as regards the disembedded operationability of the incorporation theory for European companies seeing a dramatic increase in the mobility increase of companies, is still in search of the best legislative fix. ${ }^{69}$

This change in the German approach, which has led to a larger role for unofficial, indirect forms of law-making, ${ }^{70}$ has important lessons to offer for our current and future appreciation of the European company law scene. It is here where we would still harbour hopes as to the preservation not only of difference with regard to the long-standing legal and socioeconomic cultures in the Member States but also with regard to the preservation of an open eye for the forms in which law reform has been taking place in recent years across the globe.

67 See section 3.6 of the German Corporate Governance Code, available at: $<$ http://www.corporate-governancecode.de/eng/download/E_CorGov_Endfassung_June_2006_highlighted.pdf >

68 Christian Kersting and Clemens Christian Schindler, 'The ECJ's Inspire Art Decision of 30 September 2003 and Its Effects on Practice', 4 German Law Journal (2003) p. 1277.

69 Dammann, loc. cit. n. 29.

70 The Code's recommendation in section 3.6, see supra n. 38 [67 ???], has already found followers. See, for example, the 2006 Corporate Governance Report from the METROGROUP, available at: $<$ http://www.metrogroup.de/servlet/PB/show/1119290/GB2006-CorporateGovernance-Bericht-de.pdf $>$, which states explicitly that the Group has endorsed the Code's recommendation to prepare meetings of the supervisory board separately among the shareholder representatives. 


\subsection{The 'European company law scene': overcoming diversity?}

The current European company law scene is characterised by an interesting tension between different trends and dynamics. When European scholars assessed the prospects of company law in Europe a couple of decades ago, no one doubted its centrality in the making of a more integrated market, both economically and politically. ${ }^{71}$ A few decades down the road, the picture looks much different. What began with high hopes for harmonised and unified corporate law rules among the EC Member States eventually resulted in a series of increasingly long and exhausting law-making initiatives, the success of which in many cases depended on or was prevented by national resistance politics. While the European legislator made considerably little progress in the area of company law, ${ }^{72}$ this was not the case for capital markets law, where various regulations came out of Brussels. With regard to the diversity of company laws in Europe, this was for a long time and, indeed, until very recently seen as a particular feature and characteristic aspect of the European company law scene. While it made consensus finding difficult in areas where change was recognised as being desirable, these obstacles made everyone sensitive to the existing variations in corporate law regimes and culture. The latter was always taken with a grain of salt among Europeans: while it reflected on the diversity within Europe, it was also seen as a problem with regard to corporate mobility in Europe and the attractiveness of European firms for international investors.

This diversity has recently come to be seen in a different light. Reform attempts in recent years have regularly included eloquent references - and reverences - to the existing diversity. At the same time, a number of developments suggest that the time for diversity might have come. For one, the Commission has taken several steps toward reinvigorating law reform in this area. These have grown out of the lengthy adoption process

71 Clive Schmitthoff, 'The Future of the European Company Law Scene', in Clive Schmitthoff, ed., The Harmonisation of European Company Law (London, The United Kingdom National Committee of Comparative Law 1973) p. 3.

72 Charlotte Villiers, European Company Law: Towards Democracy? (Aldershot, Ashgate/Dartmouth 1998). 
for two recent company law directives, one concerning corporate takeovers and the other one to the creation of a European Company Statute. $^{73}$ Both were examples of drawn-out, tiresome and complex negotiation struggles, one of which occupied lawmakers for some thirty years, while the other one occupied almost half of that. In gearing up for a safe adoption of the Takeover Directive, the Commission initiated an expert committee process out of which grew, in quick succession, two of the first comprehensive reports on the law relating to takeovers and the state of European company law in general. ${ }^{74}$ These reports did not remain alone for long. At both the European and the Member State level, we are seeing a plethora of committee reports, expert findings, recommendations and self-regulatory codes. For the Commission, this has lead to a certain differentiation of its law-making agenda and methodology. Realising the political obstacles that stand in the way of harmonisation in specific core areas (e.g. board composition), the turn to soft law, benchmarking and self-regulation promises a viable alternative.

However, there is another development that has a great impact on the shaping of the European company law scene. The already mentioned case law of the ECJ has dramatically altered the framework within which European managers are thinking about where to incorporate. The Court's rejection of national governments' attempts at preventing foreign European companies form forming subsidiaries in another European state has also put Member State lawmakers under increased pressure to revisit their existing company law regimes. Hence, following the case law in Centros (1999), Überseering (2002) and Inspire Art (2003), national governments throughout Europe have begun to make far-reaching changes to their applicable company law rules to render their legal frameworks attractive under incorporation considerations. ${ }^{75}$

73 Teichmann, loc. cit. n. 53, available at: <http://www.germanlawjournal.com>.

74 The so-called 'Winter Reports I and II', named after their chairman, Dutch law professor Jaap Winter. See also Frits Bolkestein, 'The Takeover Directive: A Commission Perspective Address', Speech at the Centre for European Policy Studies, Brussels 4 March 2003; Silja Maul and Athanasios Kouloridas, 'The Takeover Bids Directive', 5 German Law Journal (2004) p. 355.

75 Kilian Bälz and Teresa Baldwin, 'The End of the Real Seat Theory (Sitztheorie): The European Court of Justice Decision in Ueberseering of 5 
It is against this two-fold background that we have to assess the current European company law scene. The debate concerning the degree to which the ECJ's case law might have initiated a US-style process of regulatory competition is still ongoing. ${ }^{76}$ At the same time, the shape and structure of company law in Europe seems to be driven to a large extent by the already mentioned myriad forms of soft law and indirect regulation that have come to the fore in recent years. ${ }^{77}$ Suffice it to point to the multi-level nature of these processes at the EU and the domestic Member State level to show how this levelled structure is eventually much more complicated, due to the fact that the relevant norms grow out of reports, codes and other forms of soft law. This makes a straightforward assessment of the changes in the law dependent on the changes on the ground. In other words, without a better view of how codes are implemented, how firms are actually responding to various suggestions of indirect and voluntary regulation, there can hardly be a satisfying evaluation of the changing company law scene. ${ }^{78}$ What really matters in this respect, however, is that without a proper assessment of the changes 'on the ground' we will fail to appreciate how these many soft and indirect forms of norm-making, andthe many ways in which companies have been marketing their commitment to specific corporate governance or corporate social responsibility standards, are reflective of an important shift in law-making.

November 2002 and its Impact on German and European Company Law', 3 German Law Journal (2002), available at: <http://www.germanlawjournal.com/current_issue.php?id=214>.

76 David Charny, 'Competition among Jurisdictions in Formulating Corporate Rules: An American Perspective on the "Race to the Bottom" in the European Communities', 32 Harvard International Law Journal (1991) p. 423; Klaus Heine and Wolfgang Kerber, 'European Corporate Laws, Regulatory Competition and Path Dependence', 13 European Journal of Law and Economics (2002) p. 47; Stefano Lombardo, Regulatory Competition in Company Law in the European Community: Prerequisites and Limits (Frankfurt am Main, Lang 2002); Simon Deakin, 'Two Types of Regulatory Competition: Competitive Federalism versus Reflexive Harmonisation. A Law and Economics Perspective on Centros', 2 Cambridge Yearbook of European Legal Studies (1999) p. 231; Zumbansen, loc. cit. n. 15.

77 For an excellent analysis, see Anna di Robilant, 'Genealogies of Soft Law', 54 Am. J. Comp. L. (2006) p. 499.

78 See, e.g., Eddy Wymeersch, 'Enforcement of Corporate Governance Codes', ECGI Law Working Paper No. 46/2005 (2005). 
While the noted cases of national resistance to company law harmonisation put the political nature of corporate law in the spotlight, this space is rather dimly lit when it comes to soft law and self-regulation. Ironically, these norms are regularly not presented as law at all, because they do not have their origin in the state nor are they equipped with the traditional enforcement instruments that we know from state-made laws.

Given their apparent distance from the state - and their proximity to the market - soft laws are understood as private norms without any real footing in the political sphere of the state's law-making arena. ${ }^{79}$ It is this removal of indirect corporate law regulation from the political sphere that provokes the question whose interests are really served in the long run in this scenario. Given that a certain lobbying group succeeds in dominating the market for ideas with a certain concept for a while, what happens if the market begins to shift? Not only does the formerly successful concept allegedly lose the support of other market actors, but dependent personnel, employees, creditors and others involved with the firm might also suffer from a change in corporate organisation. We might just think this a natural effect of market actors' self-regulation and accept them as collateral. We might also, however, stop to think whether self-regulation can adequately capture and channel all of the involved stakeholders' concerns in the different features of the firm's organisation and governance. In other words, where we pursue corporate law reform and realise the need to overcome political deadlock that arises from path dependent, deeply embedded, politically, legally and culturally backed regulatory regimes, we would be well advised not to dismiss these features of embeddedness and the role of the law in this context.

What should be seen as the most pressing of challenges in this regard is how to reconnect our ongoing assessment of the fast changing and continuously evolving modes of transnational governance, in the European Union $^{80}$ and generally, ${ }^{81}$ with a critical inquiry into national law-making

79 Di Robilant, loc. cit. n. 77; see also Daniela Caruso, 'Private Law and StateMaking in the Age of Globalization', 39 N.Y.U. J. Int'l L. \& Pol. (2006) p. 1.

80 See the excellent analysis by Möllers, loc. cit. n. 51 .

81 See e.g., Craig Scott and Robert Wai, 'Transnational Governance of Corporate Conduct through the Migration of Human Rights Norms: The Potential of Transnational "Private” Litigation', in Christian Joerges, Inger- 
trajectories and the justifications offered in their support. One of the institutions engaged in a complex, interwoven process of negotiation facilitation and promotion of best practices is the European Corporate Governance Forum, ${ }^{82}$ established in pursuance to a recommendation of the Winter II Group in their November 2002 report on European Company Law. ${ }^{83}$ The expert commission made it clear that such a structure, while facilitating a process and eventual results that would themselves be 'voluntary and non-binding', would be necessary in order to effectively work towards an improvement of corporate governance regimes. ${ }^{84}$ In fact, what we can observe to be arising from the European Corporate Governance Forum's work in recent times is a far-reaching collectionof policy recommendations and lawmaking proposals that are portrayed as resulting from a quasi-natural process of almost technical content. ${ }^{85}$ 'Good corporate governance' has emerged as the regularly used formula to express the plethora of considerations that have informed the deliberations among the forum's members. In the light of the alluded-to contestations of a convergence of corporate governance regimes and the ongoing explorations into the different elements of corporate governance, we are asked to further assess the merits of regulatory competition ${ }^{86}$ and the

Johanne Sand and Gunther Teubner, eds., Transnational Governance and Constitutionalism (Oxford, Hart 2004) p. 287; Hannah Buxbaum, 'Transnational Regulatory Litigation', 46 Va. J. Int'l L. (2006) p. 251; GralfPeter Calliess and Peer Zumbansen, 'Rough Consensus and Running Code: Towards a Theory of Transnational Law Making', forthcoming.

Jaap Winter, Report of the High Level Group of Company Law Experts on a Modern Regulatory Framework for Company Law in Europe (2002) p. 73, available at: $<$ http://ec.europa.eu/internal_market/company/docs/modern/report_en.pdf>.

Simon Deakin, 'Regulatory Competition versus Reflexive Harmonisation in European Company Law’, in Daniel C. Esty and Damien Geradin, eds., Regulatory Competition and Economic Integration: Comparative Perspectives (Oxford, Oxford University Press 2001) p. 190; Heine and Kerber, loc. cit. n. 76. 
apparent triumph of a finance perspective on the corporation. ${ }^{87}$ To be sure, 'good (corporate) governance' results from an intricate and complex process of ongoing political contestation and organizational experimentation. The latter is driven by economic competition and stakeholder dynamics that have begun to surpass the post-war paradigm of "industrial pluralism" to include today a much wider and more differentiated wealth of societal rationalities. The corporation of the $21^{\text {st }}$ century can only inadequately be captured through the polarity of shareholder and stakeholder interests. Instead, as both constituencies are transforming our description of the firm itself must change. Elements of change include corporations' assumption of large-scale public functions with regard to old-age pensions and public service delivery, far-reaching alterations of corporations' ownership structures and, finally, the degree to which firms become ever-more versatile and flexible organizations within a transnational knowledge economy. The concluding section will explore these perspectives now in more detail.

\section{The learning firm}

\subsection{The transnational regulatory challenges of corporate governance reform}

This paper began by taking a perspective on the role of the employee in the firm. This focus has helped to illustrate the current regulatory framework for workers' involvement in firm management. Moreover, a study of contemporary developments in corporate governance has revealed that a discussion of co-determination forms but a part of a much larger reflection process on corporate governance rules. While there has been a long-standing debate as to the substantive goals of corporate law regulation, ${ }^{88}$ this discussion has been rendered intricately more complex due in part to the fact that the perspectives on corporate law have been

87 Critically: William Lazonick and Mary O’Sullivan, 'Maximizing Shareholder Value: A New Ideology for Corporate Governance', in Lazonick and O’Sullivan, op. cit. n. 4, at p. 11.

88 See, e.g., William W. Bratton, 'Berle and Means Reconsidered at the Century’s Turn', 26 Journal of Corporation Law (2001) p. 737. 
multiplied, enriched and widespread, making corporate law the 'hottest game in town' ${ }^{89}$ Another reason why corporate law is increasingly recognised as a very promising field in terms of research and reform potential $^{90}$ also has to do with the field's fascinating and challenging regulatory dimensions. The proliferation of law-making arenas in the area of corporate law at the domestic, transnational and international level constitutes a prime challenge to traditional understandings of domestic bodies of corporate law with an occasional comparative glance to the right or the left of one's borders. Instead, corporate law has advanced to being one of the most highly researched fields in terms of doctrinal, comparative, economic, organisational, historical and political approaches. ${ }^{91}$ Before long, the immense impact of these changes will be noticed and translated into core corporate law curricula as well. The changing forms of law-making and the ensuing multi-jurisdictional competition between official and unofficial, soft and hard norms in corporate regulation constitute a formidably complex landscape, the exploration of which has only just begun.

The focus on management and employees, however, was taken to open the door to an analysis of the corporation that would not limit its inquiry to traditional elements of monitoring management, even if that included occasional assessments, for example, of the German two-tier board and worker co-determination in supervisory boards. ${ }^{92}$ Instead, the moving of employees into the present corporate governance spotlight was aimed at eventually gaining a better picture of what constitutes 'good' corporate governance on the organisational level. It is this level, which is often neglected in corporate law scholarship, that remains for the most part within a rights paradigm of the corporation. ${ }^{93}$ While the combination of

89 Richard Buxbaum, 'New Owners and Old Managers: Lessons from the Socialist Camp', 18 Del. J. Corp. L. (1993) p. 867 at p. 868.

90 Horst Eidenmüller, 'Forschungsperspektiven im Unternehmensrecht', 62 Juristenzeitung (2007) p. 487.

91 See the observations of Brian R. Cheffins, 'The Trajectory of (Corporate) Law Scholarship', 63 Cambr. L. J. (2004) p. 456.

92 Detlev Vagts, 'Reforming the "Modern" Corporation: Perspectives from the German', 80 Harvard L. Rev. (1966) p. 23.

93 See, e.g., Reinier Kraakman, Paul L. Davies, Henry Hansmann, Gérard Hertig, Klaus J. Hopt, Hideki Kanda and Edward B. Rock, The Anatomy of 
structural analysis of the assigned rights of those invested in the corporation with a particular view on the economic results of a particular regime has the advantage of illuminating the tensions among different economic interests within and around the corporation, ${ }^{94}$ it appears to fall short of capturing the processes and institutional dimensions of the firm in operation. $^{95}$

\subsection{Beyond the shareholder v. stakeholder divide: the Strine- Bainbridge debate of 2007}

Without a better understanding of the processes within the firm that result from an institutional interaction within and outside the firm's boundaries, it is hard to imagine one would ever be in a position to make reasonable assessments about the connection between corporate governance and economic performance. The picture changes, however, if the concept of corporate governance is redefined by drawing on the wider institutional perspective alluded to before. Where varieties of capitalism scholars have importantly advanced our understanding of the market structures that are conducive to and interacting with particular governance strategies and structures, this perspective must be complemented in two ways. One is the integration of a regulatory theory approach to the understanding of corporate governance developments. Given the proliferation of norm producers, localities and spheres for corporate rule-making, any assessment of corporate governance developments must take this regulatory dimension into account.

The second complementing perspective is directed at the structures of the corporation itself. The two models that we have learned to identify as being situated at opposite ends of the spectrum are the nexus-of-contracts

Corporate Law: A Comparative and Functional Approach (Oxford, Oxford University Press 2004).

94 Henry Hansmann, Reinier Kraakman and Richard Squire, 'Law and the Rise of the Firm', 119 Harv. L. Rev. (2006) p. 1333.

95 Lazonick, loc. cit. n. 21, highlighting the relevance of altogether three 'social conditions', namely strategic control, organisational integration and financial commitment, as prerequisites for enhanced economic development. See also Whitley, loc. cit. n. 21, at pp. 871-874: identifying different innovation form in correlation with particular types of firms. 
conception of the corporation, ${ }^{96}$ on the one hand, and the corporation as a social/political/organic entity, ${ }^{97}$ on the other. A recent articulation of the corporation as a 'social institution' was provided by Vice Chancellor Leo Strine, Jr., who argued that

both management and labour are likely to view a public corporation as something more than a nexus of contracts, as more akin to a social institution that, albeit having the ultimate goal of producing profits for stockholders, also durably serves and exemplifies other societal values. In particular, both management and labor recoil at the notion that a corporation's worth can be summed upentirely by the current price the equity markets place on its stock, much less that the immediate demands of the stock market should thwart the longterm pursuit of corporate growth. ${ }^{98}$

An intimate expert of US corporate governance politics with an ear close to the ground, Strine aptly identifies the blind spots in the reigning and raging 'corporate governance industry' made up of 'public pension fund administrators, proxy advisory and corporate governance ratings organisations, corporate law scholars, and business journalists'. ${ }^{99}$ Strine directs his critique at the heart of the dominant school of thought, which contends that the Berle and Means challenge of overcoming the separation of ownership and control still stands. In contrast, Strine argues that given

96 Arman A. Alchian and Harold Demsetz, 'Production, Information Costs, and Economic Organization', 62 American Economic Review (1972) p. 777; Eugene Fama and Michael C. Jensen, 'Separation of Ownership and Control', 26 Journal of Law and Economics (1983) p. 301. For a recent endorsement and interesting discussion of the relationship between contract and enabling corporate law, see Henry Hansmann, 'Corporation and Contract', 8 Am. L \& Econ. Rev. (2006) p. 1 at p. 1: 'The conventional wisdom today is that the internal affairs of business corporations are, in fact, almost completely contractual.'

97 Adolf A. Berle, The 20th Century Capitalist Revolution (New York, Brace 1954); David Wheeler and David Grayson, 'Business and Its Stakeholders', 32 Journal of Business Ethics (2001) p. 101; Peter Cornelius and Bruce Kogut, 'Creating the Responsible Firm: In Search for a New Corporate Governance Paradigm', 4 German Law Journal (2003) p. 45.

98 Strine, loc. cit. n. 13, at p. 4.

99 Ibid., at p. 8. 
the high concentration of stocks in institutional investors, the Berle and Means equation has been reversed, now in favour of stockholders. But who are they? For one thing, the reality of stock market-based old-age pensions turns most employees into 'forced' capitalists, although they hardly 'own' anything directly. The owners are large institutional investors, intermediaries between employees and the firm. ${ }^{100}$ At the heart of Strine's critique, then, is his concern with an unceasing flow of literature demanding shareholder empowerment against management that stands in bizarre contrast to the disassociation of employees' ownership from exercising long-term, pension-oriented rights vis-à-vis 'their' corporation. He thus finds it particularly troubling that most of the current corporate responsibility and corporate governance efforts are made without the awareness that they eventually serve to empower not those with long-term interests in the viability of the corporation but rather intermediaries with less clearly demarcated interests, which might frequently be directed towards high short-term returns than long-term sustained performance.

Immediately contested, ${ }^{101}$ Strine's suggestions focus on appropriate means of shareholder empowerment precisely with the goal of identifying the long-term orientations of a firm's strategic outfit in order to disclose to stockholders in greater detail where a company stands and where its dominating investors intend to take it. ${ }^{102}$ Instead of 'feeding the market beast', as was the case before the market meltdown in Enron and Worldcom, efforts should be made to improve disclosure rules that would 'enable managers to focus more on sustainable, long-term corporate growth and less on the market's short-term expectations. ${ }^{, 103}$ Interestingly enough, it is the critic of Strine's common sense and shared interests approach who returns the analysis to an atomised interest pluralism model, which allows him to purportedly dismiss Strine's contentions regarding

${ }^{100}$ Ibid., at p. 11. Strine calls this the 'separation of ownership from ownership'.

${ }^{101}$ Stephen M. Bainbridge, 'The Shared Interests of Managers and Labor in Corporate Governance: A Comment on Strine', UCLA Public Law and Legal Theory Research Paper Series, Research Paper No. 07-15 (2007), available at: $<$ http://ssrn.com/abstract $=985683>$.

102 Strine, loc. cit. n. 13, at p. 29, available at: $<$ http://ssrn.com/abstract $=989624>$.

103 Ibid., at p. 30. 
such shared interests. Claiming that the degree of diversity among the different corporate stakeholders effectively defeats any contention of shared values between the firm's constituencies, Bainbridge evades the central challenge that Strine formulates, namely, to recognise that both management and employees share a basic interest in the sustained success of a business enterprise. Regrettably, for the time being, Bainbridge dismisses this claim, without pursuing further the idea what it would mean for our understanding of a firm's constituencies and the firm itself if we adopted a more wholesome approach to the firm and its stakeholders.

\subsection{Corporate decision making in the knowledge society}

In the following, I want to suggest an alternative perspective on the corporation. For this purpose, I put forward the thesis that neither the contractual nor the interest pluralism paradigms of the corporation can fully illuminate the internal workings of the firm. In particular, neither approach can adequately identify or assess the processes by which knowledge is generated, disseminated and executed within the corporation or, in other words, which processes in fact precede and inform any decision made by corporate management. While the contract model of the corporation remains confined to explaining corporate decision making with regard to agreements among the firm's stakeholders, even in cases of so-called 'incomplete contracts', ${ }^{104}$ the interest pluralism model of the corporation tends to one-sidedly focus on identifiable interests of specific stakeholders of the firm such as employees, unions or creditors. ${ }^{105}$ This also appears to be true in the most recent Strine-Bainbridge dialogue. In contrast, a possibly more promising perspective on the firm's institutional nature in making decisions possible could start with the premise that the elements shaping corporate decisions are never in a static, foreseeable or fully determinable state. Rather, corporate decision making by necessity involves a high-risk assessment of uncertain development trajectories, market strategies and product conceptualisations. The complexity of the

${ }^{104}$ For a critique, see William W. Bratton and Joseph A. McCahery, 'Incomplete Contracts Theories of the Firm and Comparative Corporate Governance', 2 Theoretical Inquiries in Law (2001) p. 1.

${ }^{105}$ For a critique, see Gunther Teubner, 'Enterprise Corporatism: New Industrial Policy and the "Essence” of the Legal Person', 36 Am. J. Comp. L. (1988) p. 130. 
field to be assessed by management must be reflected in the way in which we speak about the regulation of corporate activity. From this perspective, then, the firm itself moves into the centre of attention. In other words, corporate governance that claims to effectively address the core challenges of governing a corporation must take the particular features of a firm's decision-making processes into consideration.

Accordingly, it is this second complementary perspective that will be unfolded in more detail in the remainder of this paper. The key to understanding the contemporary corporation in the political economy of the de-territorialised knowledge economy is to focus on its capacity to remain innovative. ${ }^{106}$ The firm's capacity to engage in innovative production depends on its ability to constantly grow, adapt and learn. This it can do by letting go of traditional modes of command and control and instead embracing an ironic, detached, reflective and post-heroic attitude to corporate governance and management. The corporation becomes an 'interpreting system that constantly observes its environment, its markets, competitors, customers and suppliers in search of gaps that it may fill itself. The corporation is under incessant pressure to develop and fill its own niche while everything else remains in constant change, including its niche.'107 Our urgently sought definition of the corporation's responsibilities, its public duties and obligations to society at large, especially in an era of scandalous corporate crime, depends entirely on our understanding of the firm itself. It is here that we recognise the relevance for our theme of the fierce battle between shareholder value- oriented systems of corporate control and those that place a higher emphasis on workers' voice, participation, industrial relations and a wider consideration of the firm's stakeholders. ${ }^{108}$ Whether we emphasise the shareholder or the stakeholder dimension of the firm will have a significant impact on our assignment of duties and obligations to the

106 See O’Sullivan, loc. cit. n. 6.

107 Dirk Baecker, Postheroisches Management (Berlin, Merve 1994) p. 75 (translated by the author).

108 See Hansmann and Kraakman, loc. cit. n. 7, on the one hand, and William W. Bratton, 'Enron and the Dark Side of Shareholder Value', 76 Tul. L. Rev. (2002) p. 1275, on the other. 
firm. ${ }^{109}$ This is particularly relevant with regard to disclosure. ${ }^{110}$ In cases where corporate governance reform is predominantly concerned with shareholders, the emphasis is likely to remain placed - at least for the time being - on improvements in financial auditing schemes. In contrast, if we were to focus on an improved environmental accountability of the firm, we would indeed direct our initiatives at other areas of corporate organisation. In fact, environmental internal auditing constitutes a prime example of the latter developments in environmental corporate selfregulation. ${ }^{111}$ In other words, the question of the firm's responsibilities cannot be separated from a more refined understanding of the firm in its various, highly differentiated and specialised contexts.

From the perspective of the firm within a functionally differentiated knowledge society, even the connection made between the political economy of the firm and the firm's environmental (or wider social) responsibilities would still provide only an insufficient account of the corporation itself. Today's large, publicly held and globally operating firms escape clear definitions, both with regard to their core activities or 'competences'112 and their organisational structure. Increasingly, firms have become unbounded, borderless and virtual, with activities that span multiple areas of industry, manufacture, products or services. Echoing many of the challenges that the state faces today in a complex society, the firm constitutes a highly complex organisation that operates in a volatile regulatory and competitive environment, which is at its heart characterised by a fast evolving body of specialised knowledge. We should thus reject both overly simplistic categorisations of the firm as either shareholder- or stakeholder-oriented, as the firm of the twenty-first century challenges our learned ways of organising social behaviour. Shifting both the corporate

${ }^{109}$ Simon Deakin and Suzanne J. Konzelmann, 'Learning from Enron', 12 Corporate Governance (2004) p. 134.

110 See Hanno Merkt, Unternehmenspublizität (Tübingen, Mohr Siebeck 2001).

111 See Eric Orts, 'Reflexive Environmental Law', 89 Northwestern University Law Review (1995) p. 1227 at pp. 1303-1304; Michael Power, 'Constructing the Responsible Organization: Accounting and Environmental Representation', in Gunther Teubner, Lindsay Farmer and Declan Murphy, eds., Environmental Law and Ecological Responsibility: The Concept and Practice of Ecological Self-Organization (Chichester, Wiley 1994) p. 369.

112 C.K. Prahalad and Gary Hamel, 'The Core Competence of the Corporation', 68 Harv. Bus. Rev. (1990) p. 79. 
social responsibility [CSR] and the corporate governance debate away from the control-oriented images of the corporation, with its focus on the struggle between shareholders and stakeholders, is an essential first step in beginning to rephrase the question of the firm's societal functions. Questioning the definitional clarity of CSR's term 'social' as such, the firm must be viewed within a complex web made up of socio-economic, political and cultural factors, in which the corporation is embedded. The various functions that a corporation is assuming have repercussions on the evolution of corporate governance well beyond an oppositional model of shareholder v. stakeholder interests.

From the perspective of society as an ongoing communication process of different rationalities, corporate governance can adequately be understood as an ongoing process of organisational experiments ${ }^{113}$ within a constantly evolving business enterprise, operating in a polycontextual environment. It is in this light that the ongoing discussion over the convergence or divergence of corporate governance regimes must take into account the particular embeddedness of the firm within historically grown, and functionally evolving socio-economic and political contexts. Today's corporations are placed within a constantly changing environment that is determined functionally rather than territorially or politically. While specific local regulatory influences on the operation of the firm are of importance, the firm's corporate governance regime is shaped by the functional elements of the firm's operation. For example, with corporations' increasingly important assumptions of formerly public functions such as welfare, pensions or medical care, it has long become questionable whether a corporation can be adequately described as either private or public in nature. While such contestations of the nature of the business enterprise already have a considerable legacy, ${ }^{114}$ the functionalist critique of both the shareholder $\mathrm{v}$. stakeholder paradigm of corporate governance and the public-private divide in determining the nature of the firm goes much further still. From the perspective of societal functional differentiation, it is a mere historical contingency that the discussion of

${ }^{113}$ Amin and Cohendet, op. cit. n. 32, at p. 117: 'The key management challenge, thus, is to strike a delicate balance between existing routines and the exploration of novelty.'

${ }^{114}$ See only John Dewey, 'The Historic Background of Corporate Legal Personality’, 35 Yale L. J. (1926) p. 655. 
corporate governance would be dominated - for some time - by such connotations as 'shareholders' and 'stakeholders', on the one hand, and the public v. private nature of the corporation, on the other. While varieties of capitalism scholarship succeeds in reiterating the contextuality of corporate governance development, it still has to be developed further to move away from contentions of path dependency, and thus upheld claims of persisting divergence, in order to recognise the complexity in which the business corporation is the collision site of different societal rationalities. 